\title{
Steps to a Sustainable Public Health Surveillance Enterprise
}

\section{A Commentary from the International Society for Disease Surveillance}

\author{
Nabila Mirza, ${ }^{1}$ Tera Reynolds, ${ }^{1}$ Michael Coletta, ${ }^{2}$ Katie Suda, ${ }^{3}$ Ireneous Soyiri, ${ }^{4}$ Ariana Markle, \\ Henry Leopold, ${ }^{6}$ Leslie Lenert, ${ }^{7}$ Erika Samoff, ${ }^{8}$ Alan Siniscalchi, ${ }^{9}$ Laura Streichert ${ }^{1}$ \\ 1 International Society for Disease Surveillance; $\mathbf{2}$ National Association of County and City \\ Health Officials; 3 University of Tennessee; 4 Monash University; 5 University of California, Los \\ Angeles; 6 HealthWizer; 7 University of Utah Health Care; 8 University of North Carolina - \\ Chapel Hill; 9 Connecticut Department of Public Health
}

\begin{abstract}
More than a decade into the $21^{\text {st }}$ century, the ability to effectively monitor community health status, as well as forecast, detect, and respond to disease outbreaks and other events of public health significance, remains a major challenge. As an issue that affects population health, economic stability, and global security, the public health surveillance enterprise warrants the attention of decision makers at all levels.

Public health practitioners responsible for surveillance functions are best positioned to identify the key elements needed for creating and maintaining effective and sustainable surveillance systems. This paper presents the recommendations of the Sustainable Surveillance Workgroup convened by the International Society for Disease Surveillance (ISDS) to identify strategies for building, strengthening, and maintaining surveillance systems that are equipped to provide data continuity and to handle both established and new data sources and public health surveillance practices.

Keywords: disease surveillance, enterprise, sustainable, policy, information technology, epidemiology

Correspondence: Istreichert@syndromic.org

Copyright @2013 the author(s)

This is an Open Access article. Authors own copyright of their articles appearing in the Online Journal of Public Health Informatics. Readers may copy articles without permission of the copyright owner(s), as long as the author and OJPHI are acknowledged in the copy and the copy is used for educational, not-for-profit purposes.
\end{abstract}

\section{Introduction}

At a time when populations are changing and disease outbreaks and other events of public health significance pose increasing risks to global health, economic stability, and national security, it is essential that, as a nation, we invest in the systems needed to promote and protect the public's health. 
In 2002, the Institute of Medicine (IOM) reported that the public health system in the United States had a multitude of deficiencies that impact the ability to effectively conduct public health surveillance. These included outdated and vulnerable technologies; a public health workforce lacking training and reinforcements; lack of real-time surveillance and epidemiological systems; and ineffective and fragmented communications networks. ${ }^{1}$ While considerable headway has been made since the IOM report was published, there is still evidence of a need for further improvements. A recent report by Trust for America's Health, for example, found that there are persistent gaps in the ability of state and local public health agencies to respond to events ranging from bioterrorist threats to natural disasters and disease outbreaks. ${ }^{2}$ The question is-how can we reduce these gaps?

Nationwide and globally, rapid changes in health information systems, cloud computing technologies, communications, and global connections are catalyzing a re-examination of disease surveillance as an enterprise that needs coordinated and integrated system elements. Sustainable surveillance, which we define as ongoing data collection, analysis, and application, coupled with a capability to respond to novel demands, is needed to ensure that public health agencies can perform reliably regardless of shifts in public health funding and priorities. The ISDS Sustainable Surveillance Workgroup identified the following steps to maintain and advance the public health surveillance enterprise:

1. Recognize systematic and ongoing public health surveillance as a core public health function that is essential for population health, economic stability, and national security.

2. Create and support funding mechanisms that reinforce enterprise (i.e., integrated systems), rather than categorical (i.e., disease or program specific) surveillance infrastructures and activities in order to reduce inefficient silos, leverage resources, and foster synergies.

3. Oppose further cuts to spending for surveillance activities.

4. Invest in surveillance workforce development to build competencies and improve organizational capacity to utilize technological advances in surveillance practice.

5. Advance a rigorous surveillance research and evaluation agenda that will deepen the understanding of community health, identify best practices, and provide evidence for decision-making. 


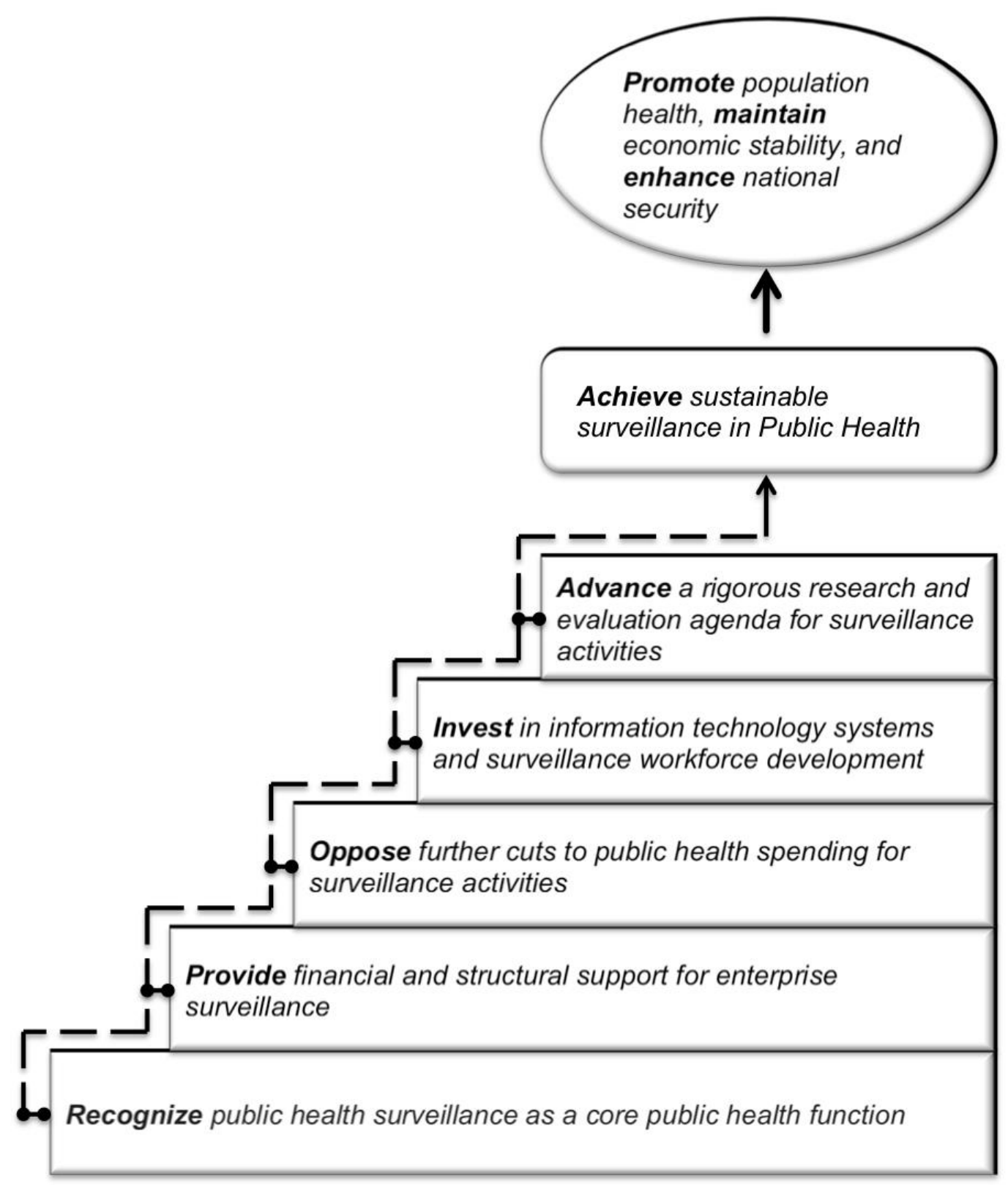

Figure 1: Recommended steps to a sustainable surveillance enterprise

\section{Background}

Public health surveillance is defined as, "the systematic and ongoing collection, management, analysis, interpretation, and dissemination of information for the purpose of informing the actions of public health decision makers." ${ }^{3}$ In addition to providing information about the health status of our communities, surveillance is a foundation of emergency preparedness, food safety, infectious disease outbreak prevention and control, chronic disease assessments, and other key areas that protect the health, economy, and security of the public. While public health surveillance policy and practice have been indicated as priorities for policymakers at the national 
and global levels, ${ }^{4-7}$ questions remain about how to move forward from planning to implementation, especially in a time of critical cuts to federal funding.

Progress in health information technology (IT) and the increased use of electronic data and new data streams offer great potential for innovation in surveillance science and practice. For instance, the self-reporting of health information through social media (e.g., Twitter), as well as crowdsourcing projects such as Flu Near You (www.flunearyou.org) offer new options for collecting timely data. In addition, the Health Information Technology for Economic and Clinical Health (HITECH) Act, ${ }^{8}$ legislated as part of the American Recovery and Reinvestment Act (ARRA) of 2009, is fueling the adoption of electronic health record (EHR) systems in the U.S. ${ }^{9}$ In return for financial subsidies to implement EHR systems, hospitals and doctors are required to share data for public health purposes ${ }^{9}$ with the intent to improve both population health outcomes and the quality of clinical practice. Sustainable surveillance systems have the potential to advance both of these goals. ${ }^{10}$

\section{The value of public health surveillance}

1. Recognize systematic and ongoing public health surveillance as a core public health function that is essential for population health, economic stability, and national security.

Public health surveillance data is the foundation of public health programs and is required for a number of purposes, including: to demonstrate the size and impact of the public health problem being addressed by a program; to identify the population groups to which additional prevention efforts should be directed; to determine whether the problem is growing in size or abating; to provide feedback to data providers; and as part of an overall program evaluation strategy.

The significant health impacts and economic costs of disease outbreaks illustrate the critical importance of effective public health surveillance and rapid response, as well as the cost of inaction. ${ }^{11}$ Table 1 provides examples of the health and financial burdens posed by some naturally occurring and intentional infectious disease outbreaks. 
Table 1: Examples of Health Impacts and Economic Costs Associated with Disease Outbreaks and Epidemics

\begin{tabular}{|c|c|c|c|}
\hline Disease & Transmission & Health Impact & Financial Cost \\
\hline $\begin{array}{l}\text { Severe Acute } \\
\text { Respiratory } \\
\text { Syndrome (SARS), } \\
\text { Global, } 2002 \text { and } \\
2003\end{array}$ & Droplet (Direct) & $\begin{array}{l}8,096 \text { infected, } \\
\text { including almost } \\
800 \text { deaths }^{12}\end{array}$ & $\$ 40-\$ 54$ billion $^{13}$ \\
\hline $\begin{array}{l}\text { Anthrax Attack, } \\
\text { United States, } 2001\end{array}$ & $\begin{array}{l}\text { Bioterrorism } \\
\text { (Indirect) }\end{array}$ & $\begin{array}{l}22 \text { cases, including } \\
5 \text { deaths }{ }^{14}\end{array}$ & About $\$ 320$ million $^{15}$ \\
\hline $\begin{array}{l}\text { Pandemic flu, United } \\
\text { States }\end{array}$ & Droplet (Direct] & $\begin{array}{l}\text { Projected death of } \\
\text { millions of } \\
\text { people }^{16}\end{array}$ & $\begin{array}{l}\text { Projected cost of } \$ 800 \\
\text { billion over a whole year }\end{array}$ \\
\hline $\begin{array}{l}\text { Pertussis, } \\
\text { Washington State, } \\
2012\end{array}$ & Droplet (Direct) & $\begin{array}{l}\text { Over } 3000 \text { cases } \\
\text { through early } \\
\text { July }^{18}\end{array}$ & Over $\$ 2,000$ per case ${ }^{19}$ \\
\hline $\begin{array}{l}\text { West Nile Virus, } \\
\text { Sacramento County, } \\
2005\end{array}$ & Vector (Indirect) & $\begin{array}{l}163 \text { people }^{20,21} \\
\text { infected }^{2}\end{array}$ & $\begin{array}{l}\$ 2.98 \text { million [treatment } \\
\text { cost and productivity loss] }\end{array}$ \\
\hline $\begin{array}{l}\text { Salmonella, North } \\
\text { Dakota, } 2009\end{array}$ & $\begin{array}{l}\text { Foodborne } \\
\text { (Indirect) }\end{array}$ & $\begin{array}{l}180 \text { people }^{22} \\
\text { infected }^{22}\end{array}$ & $\begin{array}{l}\$ 38,000 \text { in investigation } \\
\text { cost [travel, laboratory and } \\
\text { staff time) })^{22}\end{array}$ \\
\hline $\begin{array}{l}\text { Cholera, Latin } \\
\text { America, } 1991\end{array}$ & $\begin{array}{l}\text { Waterborne } \\
\text { (Indirect) }\end{array}$ & $\begin{array}{l}400,000 \text { cases } \\
\text { including over } \\
4000 \text { deaths }^{23}\end{array}$ & $\begin{array}{l}\$ 770 \text { million loss in food } \\
\text { trade embargoes and } \\
\text { adverse effects on tourism }\end{array}$ \\
\hline $\begin{array}{l}\text { Tuberculosis, Global, } \\
2011\end{array}$ & Droplet (Direct) & $\begin{array}{l}8.7 \text { million cases, } \\
1.4 \text { million } \\
\text { deaths }^{24}\end{array}$ & $\begin{array}{l}\text { Projected economic cost of } \\
\text { up to } \$ 8 \text { billion per year } \\
\text { between } 2013 \text { and } 2015 \text { for } \\
\text { low and middle income } \\
\text { countries }^{24}\end{array}$ \\
\hline
\end{tabular}

The values reported in Table 1 do not fully reflect additional indirect costs of diseases and their potentially crippling effects on a community, nor do they address costs that are underreported/ unreported due to lack of data. Higher rates of illness, for example, can lead to lower worker productivity, ${ }^{11}$ while premature mortality can reduce the size of the labor force, both of which have economic ramifications.

There is growing evidence that these economic and societal costs can be mitigated by surveillance systems that are stable; a stable system provides the best foundation for identifying whether the problem being addressed is getting bigger or smaller or disproportionately affecting a section of the population, etc., while still allowing flexibility to provide useful information quickly about emerging issues. The optimum mix of stability and flexibility will depend on the purpose(s) of surveillance and the particular health condition under surveillance. For example, in 
the case of SARS, an effective surveillance system has the potential to decrease the size of an epidemic by one-third and the duration by 4 weeks, with significant cost savings. ${ }^{25}$ Another study found that the early detection of an outbreak of highly infectious bacterial meningitis saved approximately $\$ 2$ for every dollar invested in infectious disease surveillance. ${ }^{26}$ Yet another evaluation of surveillance practice found that technological improvements in a sentinel influenza-like illness (ILI) surveillance system in Virginia saved over \$9,500 (1,992 hours) in staff-time during the 2007-2008 influenza seasons. ${ }^{27}$

Ongoing surveillance can also inform the design and evaluation of prevention and intervention programs in order to control the escalating costs associated with chronic diseases in the U.S. and abroad. ${ }^{28}$ Some experts forecast that chronic disease prevention programs could save up to $\$ 48.9$ billion per year by $2030,{ }^{29}$ while others predict applying electronic medical record implementation and networking to the prevention and management of chronic disease will exceed the currently projected $\$ 81$ billion in annual savings. ${ }^{30}$

\section{Enterprise models for surveillance practice and funding}

2. Create and support funding mechanisms that reinforce enterprise (i.e., integrated systems) rather than categorical (i.e., disease or program-specific) surveillance infrastructure and activities in order to reduce inefficient silos, leverage resources, and foster synergies.

Siloed surveillance systems are outdated, inefficient, and incapable of meeting today's demands for electronic data exchange and for the informatics capabilities needed to use the information for maximum benefit. Integrated programs and collaboration, on the other hand, facilitate the efficient management of the complex, varied, and proliferating issues and information sources that exist today. The nature of public health surveillance also lends itself to multiple-purpose approaches in that strategies for preventing and controlling diseases, such as West Nile virus, are to a great extent the same as for an influenza epidemic, a foodborne disease outbreak, or a bioterrorist attack. ${ }^{31}$

Technology that enhances communication and data sharing across disease programs, surveillance systems, and even across jurisdictions increases the ease of obtaining and disseminating useful information to a broad audience, including public health agencies, healthcare providers, policymakers, and the general public. ${ }^{6,32}$ This rapid information exchange not only facilitates timely response, but can also reduce emergency room visits, hospital admissions, and even costs of care. ${ }^{33}$ However, many health departments currently have systems that are not flexible enough to respond to changing health IT needs, which makes it difficult to deliver information when and where it is needed. ${ }^{4}$

Disease or program-specific funding also exacerbates program vulnerability to funding and budgetary cuts. For example, when funding is earmarked for specific purposes (e.g., emergency preparedness and associated surveillance systems), and then is reduced, such as has occurred for public health emergency preparedness cooperative agreement funding through CDC in the past seven years, ${ }^{34}$ it can undermine and reverse efforts to establish sustainable systems that serve multiple crosscutting purposes throughout public health. 
By contrast, an enterprise approach provides a cohesive framework that will better equip public health practitioners to address the challenges of processing large volumes of electronic data, and the concomitant analytical and visualization requirements. Specifically, enterprise funding supports a reliable, flexible infrastructure that can adapt to technological and information requirement changes, and allows for ongoing data collection and the integration of new data sources to advance all-hazard preparedness. A 2004 White House memo acknowledged how programmatic funding can lead to inefficiencies and redundancies in system acquisitions and usage and called for applying technological and human resources across programs. ${ }^{35}$

By encouraging collaboration within and between departments, surveillance professionals can take advantage of shared platforms and resources to optimize data collection, analysis, storage, and dissemination, thus helping to reduce operational costs and improve efficiency. For example, collaboration could create opportunities for the effective integration of syndromic and reportable disease data for public health use. ${ }^{36}$

\section{Stable funding and sustainable surveillance}

\section{Oppose further cuts to spending for surveillance activities.}

A lack of consistent and sustainable funding is hampering the necessary expansion and improvement of public health surveillance systems at local, state, and national public health agencies. A 2010 survey of local health departments conducted by the National Association of City and County Health Officials (NACCHO) found that $72 \%$ of local health departments reported insufficient funding as one of their major barriers to modernizing their IT systems. ${ }^{37}$

Health data collection systems that take advantage of recent technological advances have proven to be more cost effective and sustainable in the long-term. ${ }^{38}$ Stable funding is essential to supporting the adoption of hardware and software systems as they become available, leading to a robust and sustainable public health surveillance infrastructure able to integrate, manage, and communicate the plethora of data necessary to generate actionable results. ${ }^{39}$

\section{Build the base for success}

4. Invest in surveillance workforce development to build competencies and improve organizational capacity to utilize technological advances in surveillance practice.

The new age of disease surveillance requires a skilled public health workforce able to manage large volumes of increasingly complex electronic information, to understand the data flows, and to extract meaning from them. This calls for sophisticated and integrated competencies in public health informatics, epidemiology, statistics, and other areas, and the ability to present findings, draw conclusions, and make recommendations based on surveillance data. Furthermore, in addition to needing people who can effectively operate existing surveillance systems and carry out tasks (such as the onboarding process for collecting newly available EHR data) there is also demand for people who can identify and assess new opportunities for surveillance and design new systems that take advantage of these opportunities. ${ }^{6}$ 
Attracting and retaining experts in these fields is especially challenging in light of the comparatively low base salaries allotted to public health workers compared to the salaries of technology-intensive positions in other sectors. ${ }^{40}$

To align the surveillance workforce with new demands, the ISDS Sustainable Surveillance Workgroup suggests the following approaches:

- Provide training programs for existing and prospective public health workers to equip themselves with the necessary expertise and skills to work in rapidly evolving IT systems.

- Promote public health careers at the primary, secondary, undergraduate, and graduate levels across disciplines.

- Provide competitive salaries to recruit and retain a workforce skilled in public health surveillance and informatics.

\section{Toward informed decision-making}

5. Advance a rigorous research and evaluation agenda that will deepen the understanding of community health, identify best practices, and provide evidence to inform decision-making.

Research and evaluation play an important role in connecting the processes of information collection, information use for decision-making, and translation of decisions to actions and measurable outcomes. Research-based evidence and evaluation results can help to identify the limitations and benefits of different surveillance procedures for better decision-making and more effective resource allocation. Investing in research and applying the rigors of science to public health surveillance questions leads to informed decisions on how best to direct efforts and resources.

In addition, periodic evaluations of surveillance infrastructures - the systems and people - are needed to assess return on investment and opportunities for quality improvement.

\section{Conclusion}

Effective and efficient surveillance systems are proven to save money and lives. The ability to detect and respond to known and emerging pathogens is central to protecting and maintaining population health. ${ }^{41}$ The breakdown or absence of a stable public health surveillance infrastructure, on the other hand, can undermine efforts to mitigate disease outbreaks and other public health events. ${ }^{31}$ Public health surveillance systems built on a strong infrastructure of core workforce competencies, information systems, and organizational capacity, ${ }^{42}$ and supported by consistent and enterprise-based funding, are essential if we are to understand and respond to the real and growing threats to population health. By providing political commitment and financial support to this issue, decision makers can play an active role in advancing the health of individuals, communities, and nations. 


\section{Acknowledgements}

ISDS thanks the following members of the ISDS Sustainable Surveillance Workgroup and others for their input to discussions and manuscript review:

Gregory Danyluk, Karen Elliott, Rennie Ferguson, Roland Gamache, Kate Goodin, Teresa Hamby, Richard Hopkins, Jeffrey Johnson, Abimbola Aman-Oloniyo, Melinda Kurtzo, Tonya McKennley, Erika Samoff, Amanda Schulte, Mika Shigematsu, Vivek Singh, Kristen Soto, Sarah Winn, Saad Zaheer, and Becky Zwickl. This work was supported by the CDC through a Cooperative agreement to the Task Force for Global Health.

\section{Corresponding Author}

Laura Streichert, PhD, MPH

International Society for Disease Surveillance

$\mathrm{Ph}:$ 617-779-7351

Email: 1streichert@syndromic.org

\section{References}

[1] Institute of Medicine (U.S.). The Future of the Public's Health in the 21st Century. Washington, D.C: National Academies Press; 2002.

[2] Levi J, Serena V, M. Segal L, St. Laurent R. Ready or Not? - Protecting the Public's Health from Diseases, Disasters, and Bioterrorism, 2010. Trust for America's Health and Robert Wood Johnson Foundation; 2010. Available at: http://www.rwjf.org/en/researchpublications/find-rwjf-research/2010/12/-ready-or-not--.html. (Archived by WebCite at http://www.webcitation.org/6GGpLzq9V)

[3] International Epidemiological Association. A Dictionary of Epidemiology. 5th ed. Oxford; New York: Oxford University Press; 2008.

[4] National Strategy for Biosurveillance. The White House; 2012. Available at: http://www.whitehouse.gov/sites/default/files/National_Strategy_for_Biosurveillance_July_2 012.pdf. (Archived by WebCite at http://www.webcitation.org/6GGvJoIwp)

[5] Public Health Surveillance and Informatics Program Office. FY 2013-2016 Strategic Plan. 2012. Available at:

http://www.cdc.gov/surveillancepractice/documents/Final_PHSIPO_FY1316_Strategic_Plan $101512 \% 283 \% 29$.pdf. (Archived by WebCite at http://www.webcitation.org/6GGvuGHrY)

[6] Smith PF, Hadler JL, Stanbury M, Rolfs RT, Hopkins RS. "Blueprint Version 2.0": Updating Public Health Surveillance for the 21st Century. J Public Health Manag Pract. 2013 MayJun; 19(3):231-9.

[7] Implementation of the International Health Regulations (2005). Sixty-Fifth World Health Assembly: World Health Organization; 2012.

[8] HITECH Act Enforcement Interim Final Rule. U.S. Department of Health and Human Services; 2009. Available at:

http://www.hhs.gov/ocr/privacy/hipaa/administrative/enforcementrule/hitechenforcementifr.h $\underline{\text { tml. (Archived by WebCite at http://www.webcitation.org/6GGni3br6) }}$ 
[9] Lenert L, Sundwall DN. Public Health Surveillance and Meaningful Use Regulations: A crisis of Opportunity. Am J Public Health. 2012;102(3):e1-7.

[10] Fine AM, Nizet V, Mandl KD. Improved Diagnostic Accuracy of Group A Streptococcal Pharyngitis With Use of Real-Time Biosurveillance. Ann Intern Med. 2011;155(6):345-352.

[11] Zhang W, Bansback N, Anis AH. Measuring and Valuing Productivity Loss Due to Poor Health: A Critical Review. Soc Sci Med. 2011;72(2):185-192.

[12] Summary of Probable SARS Cases with Onset of Illness from 1 November 2002 to 31 July 2003. World Health Organization. Available at:

http://www.who.int/csr/sars/country/table2003_09_23/en/. (Archived by WebCite at http://www.webcitation.org/6GGpdFSZc)

[13] Lee JW, McKibbin WJ. Estimating the Global Economic Costs of SARS. In: Institute of Medicine (US) Forum on Microbial Threats; Knobler S, Mahmoud A, Lemon S, et al., editors. Learning from SARS: Preparing for the Next Disease Outbreak: Workshop Summary. Washington (DC): National Academies Press (US); 2004. Available at: http://www.ncbi.nlm.nih.gov/books/NBK92473/.

[14] Jernigan DB, Raghunathan PL, Bell BP, Brechner R, Bresnitz EA, Butler JC, et al. Investigation of Bioterrorism-Related Anthrax, United States, 2001: Epidemiologic Findings. Emerging Infectious Diseases. 2002 Oct;8(10):1019-28.

[15] Schmitt K, Zacchia NA. Total Decontamination Cost of the Anthrax Letter Attacks. Biosecurity and Bioterrorism: Biodefense Strategy, Practice, and Science. 2012;10(1):98107.

[16] King DA. EPIDEMIOLOGY: Infectious Diseases: Preparing for the Future. Science. 2006;313(5792):1392-1393.

[17] Brahmbhatt M. Avian Influenza: Economic and Social Impacts. The World Bank. 2005. Available at:

http://web.worldbank.org/WBSITE/EXTERNAL/NEWS/0,,contentMDK:20663668 pagePK :34370 piPK:42770 theSitePK:4607,00.html. (Archived by WebCite at http://www.webcitation.org/6GGpwmgFu)

[18] Handwerker L. Officials Warn of Pertussis Outbreak. ABC News. 2013. Available at: http://abcnews.go.com/Health/pertussis-outbreak-worst-50-years/story?id=16814787.

(Archived by WebCite at http://www.webcitation.org/6GGq6Iyko)

[19] Centers for Disease Control and Prevention. Local Health Department Costs Associated with Response to a School-Based Pertussis Outbreak --- Omaha, Nebraska, September-November 2008. MMWR. 2011;60(1):5-9.

[20] 2005 Human WNV Case Linelist. California West Nile Virus Website. 2006. Available at: http://www.westnile.ca.gov/website/maps_data/2005_maps_data/2005 Human WNV Case Linelist.pdf. (Archived by WebCite at http://www.webcitation.org/6GGq02UAx)

[21] Barber LM, Schleier JJ, Peterson RKD. Economic Cost Analysis of West Nile Virus Outbreak, Sacramento County, California, USA, 2005. Emerging Infectious Diseases. 2010;16(3):480-486.

[22] Gehring B. Health Department Releases Costs of Salmonella Probe. Bismarck Tribune. 2010. Available at: http://bismarcktribune.com/news/state-and-regional/health-departmentreleases-costs-of-salmonella-probe/article_b638a620-2e2c-11df-afd9-001cc4c03286.html. (Archived by WebCite at http://www.webcitation.org/6GGqHxgdd) 
[23] Global Epidemics and Impact of Cholera. World Health Organization. Available at: http://www.who.int/topics/cholera/impact/en/index.html. (Archived by WebCite at http://www.webcitation.org/6GGqPnMRe)

[24] Global Tuberculosis Report 2012. Geneva: World Health Organization; 2012.

[25] Wallinga J, Teunis P. Different Epidemic Curves for Severe Acute Respiratory Syndrome Reveal Similar Impacts of Control Measures. Am. J. Epidemiol. 2004;160(6):509-516.

[26] Public Sector Consultants, Inc. and Michigan Association for Local Public Health. Analysis of the Value of Local Public Health Operations Spending. Public Health - Muskegon County. 2010. Available at: http://www.muskegonhealth.net/publications/localhealthrpts/lpho_value.pdf. (Archived by WebCite at http://www.webcitation.org/6GGqDIbKS)

[27] Kurkjian K, Woolard D, Coletta M. Cost-Effectiveness of Influenza-Like Illness Sentinel Surveillance in Virginia. Virginia Department of Health; 2008.

[28] World Bank, Disease Control Priorities Project. Disease Control Priorities in Developing Countries. 2nd ed. New York: Washington, DC: Oxford University Press; World Bank; 2006.

[29] Return on Investments in Public Health: Saving Lives and Money. Robert Wood Johnson Foundation; 2012. Available at: http://www.rwjf.org/content/rwjf/en/researchpublications/find-rwjf-research/2012/03/return-on-investments-in-public-health.html.

(Archived by WebCite at http://www.webcitation.org/6GGqffY8E)

[30] Hillestad R, Bigelow J, Bower A, et al. Can Electronic Medical Record Systems Transform Health Care? Potential Health Benefits, Savings, and Costs. Health Aff (Millwood). 2005;24(5):1103-1117.

[31] Baker EL, Koplan JP. Strengthening The Nation's Public Health Infrastructure: Historic Challenge, Unprecedented Opportunity. Health Affairs. 2002;21(6):15-27.

[32] Mariner W. Mission Creep: Public Health Surveillance and Medical Privacy. Rochester, NY: Social Science Research Network; 2007. Available at:

http://papers.ssrn.com/abstract=1033528. (Archived by WebCite at http://www.webcitation.org/6GGqmhzfh)

[33] Freudenheim M. Fast Access to Records Helps Fight Epidemics. The New York Times. 2012. Available at: http://www.nytimes.com/2012/06/19/health/states-using-electronicmedical-records-to-track-epidemics.html. (Archived by WebCite at http://www.webcitation.org/6GGqxvcox)

[34] CDC Office of Public Health Preparedness and Response. 2012 State-by-State Update Report on Preparedness and Response. Centers for Disease Control and Prevention Available at: http://www.cdc.gov/phpr/pubs-links/2012/index.htm. (Archived by WebCite at http://www.webcitation.org/6GGr5a6R9)

[35] White House Office of Management and Budget. OMB CIRCULAR A-87 REVISED. The White House; 2004. Available at: http://www.whitehouse.gov/omb/circulars_a087_2004. (Archived by WebCite at http://www.webcitation.org/6GGrBjKSM)

[36] Samoff E, Waller A, Fleischauer A, et al. Integration of Syndromic Surveillance Data into Public Health Practice at State and Local Levels in North Carolina. Public Health Rep. 2012;127(3):310-317.

[37] The Status of Local Health Department Informatics: Results from the 2010 NACCHO Informatics Needs Assessment. National Association of City and County Health Officers; 2010. 
[38] Thriemer K, Ley B, Ame SM, et al. Replacing Paper Data Collection Forms with Electronic Data Entry in the Field: Findings from a Study of Community-Acquired Bloodstream Infections in Pemba, Zanzibar. BMC Research Notes. 2012;5(1):113.

[39] Hopkins RS. Design and Operation of State and Local Infectious Disease Surveillance Systems. J Public Health Manag Pract. 2005;11(3):184-190.

[40] Tilson H, Berkowitz B. The Public Health Enterprise: Examining Our Twenty-First-Century Policy Challenges. Health Aff. 2006;25(4):900-910.

[41] Baker EL, Potter MA, Jones DL, et al. The Public Health Infrastructure and Our Nation's Health. Annu Rev Public Health. 2005;26:303-318.

[42] The Department of Health and Human Services. Public Health's Infrastructure, A Status Report to the U.S. Senate Appropriations Committee, 2001. Centers for Disease Control and Prevention; 2001. 